ACTA THERIOLOGICA

Vol. 25, 23: 295-307, 1980

\title{
Trap Use as an Indicator of Social Behavior in Mainland and Island Voles
}

\author{
Lawrence M. REICH \& Robert H. TAMARIN
}

Reich L. M. \& Tamarin R. H., 1980: Trap use as an indicator of social behavior in mainland and island voles. Acta theriol., 25, 23: 295-307 [With 4 Tables]

The social behavior of a cyling mainland population of Microtus pennsylvanicus and a non-cycling island endemic, $M$. breweri was studied. Social structure was determined by the spatial distribution of various sex, reproductive, and age classes using a grid arrangement of live traps. The response of voles of given age and sex classes to olfactory cues left by other voles of known age and sex classes in live traps was studied in the field. Differences between the two species in social behavior were looked at as contributing factors in the observed demographic differences between the species. Resident and dispersing sub-populations of each species were compared. The social behavior was also examined in each of 4 distinct phases of a single population cycle of $M$. pennsylvanicus. It was seen that the intensity of social interactions increased markedly as populating density increased. Dispersers in a cycling vole population ( $M$. pennsylvanicus) show a random social distribution, perhaps indicative of social intolerance. The dispersers in the non-cycling $M$. breweri do not exhibit this social intolerance, but are less aggressive in comparison with residents of the same species. This difference is suggested as being a factor in the differences in the population dynamics of the two species. Analysis of the response to olfactory cues left in traps reveals that olfaction primarily functions as an aid in reproduction, and is independent of major demographic changes in $M$. pennsylvanicus. It is not a major factor in the determination of social structure in either species.

[Boston University, Department of Biology, Boston, Massachusetts, USA].

\section{INTRODUCTION}

Cyclic fluctuations in population densities of Cricetid rodents of the sub-family Microtinae (including voles, lemmings, and muskrat) have been studied for a number of years (E I t o n, 1924; Kre bs \& M y e r s, 1974), yet there is still little agreement as to what regulates these cycles. In $1967, \mathrm{C}$ h it ty developed the behavior-genetic model of population regulation, which was applied by him and by $\mathrm{Krebs}$ et al. (1973) to explain vole cyles. The model supposes that the cycle is driven by natural selection acting differentially at various population densities, on individuals which differ qualitatively in the social behavior. A 
genetic link of behavior and an alteration of the gene pool through dispersal are important parts of Chitty's model.

Attempts to test the model have mostly concentrated on laboratory assays of behavior ( $\mathrm{Kre} \mathrm{b} \mathrm{s,} \mathrm{1970;} \mathrm{M} \mathrm{y} \mathrm{e} \mathrm{r} \mathrm{s} \mathrm{\&} \mathrm{Kre} \mathrm{bs,} \mathrm{1971;} \mathrm{C} \mathrm{o} \mathrm{n} \mathrm{le} \mathrm{y,}$ 1971). Field studies of behavior have been relatively few, generally being limited by the amount of behavioral data which can be generated with a minimum of interference in the normal course of the animal's life.

The present investigation is an analysis of the social behavior of natural populations of voles. Two species are compared. Microtus pennsylvanicus (Ord, 1815), the meadow vole, is widely distributed throughout northern North America, while Microtus breweri (Baird, 1857), the beach vole, is an island endemic restricted to Muskeget Island, off the coast of Cape Cod, Massachusetts. The most interesting contrast between the two species is that $M$. breweri has been found not to exibit the characteristic microtine population cycle ( $\mathrm{T}$ a m a r i n, 1977b).

Two analyses of social behavior were carried out. In the first analysis, we studied the spatial distribution of the population in terms of the occurrence of mice of given classes in adjacent trap locations on the first night only. Since the average home range of these species covers a distance greater than the distance between traps ( $\mathrm{T}$ a $\mathrm{m}$ a r i $\mathrm{n}, 1977 \mathrm{~b}$ ), this analysis may be looked at as describing the social classes of voles whose ranges abut or overlap in the field.

G e tz (1972) employed multiple capture live traps to study the social structure of vole populations. In our second analysis, we approached the same problems as Getz from a different way. Rather than using multiple capture live traps, this study used single capture live trapping for two consecutive nights. We supposed that a vole present in a trap for a night would leave a considerable amount of odor in the trap, and we carried out an analysis of social behavior as a function of the sex and age classes of those voles which produced the olfactory cues and those which were subsequently attracted to the olfactory cues left by the mouse caught the night before. The concept of olfactory communication by pheromones is well known and widespread in many rodents ( $R$ a $11 \mathrm{~s}$, 1971; J o hn s o n, 1973). Studies have shown that the substances active in olfactory communication are effective at very low dilutions (D a g g \& W ind s or, 1971), and this would suggest that their potency would not be eliminated in the time period involved in this study. In fact, Johnson (1973) points out that scents involved in a scent-marking function would be non-volatile and would linger for long periods of time. Work done in the laboratory and in the field suggest that mice 
are receptive and do react to olfactory cues left in traps ( $\mathrm{S}$ u $\mathrm{m}$ m e rlin \& Wolfe, 1973; Boonstra \& Krebs, 1976).

\section{MATERIALS AND METHOD}

Microtus pennsylvanicus was trapped on the mainland at Manomet, south of Plymouth, Massachusetts, on a site owned by the Boston Edison Company. The habitat was grassland surrounded by dense woodland. Microtus breweri is endemic to the $2.6 \mathrm{~km}^{2}$ Muskeget Island, Nantucket County, Massachusetts. The island is almost uniform sandy habitat. The ecology of the island is discussed by We therbee et al. (1972).

At each study area, 2 grids of 100 traps each were established (B and $\mathrm{E}$ on Muskeget Island, F and G at Plymouth), each arranged as $10 \times 10$ square, with 7.6 meters between trap lines (grid $G$ deviated slightly from this square arrangement). The two grids at each area were separated by approximately 30 meters. The exact orientation of the grids is described by $\mathrm{T}$ a ma rin (1977a). Grid B (Muskeget Island) and grid F (Plymouth) were both control grids, while grids $\mathrm{E}$ and $\mathrm{G}$ were removal grids. Trapping was done monthly in each area from May 1972 until October 1975, according to the following trapping regime:

$$
\begin{aligned}
& \text { Day } 0 \\
& \text { Day } 1 \\
& \text { Day } 2
\end{aligned}
$$

Longworth live traps were used, baited with oats, and cotton was supplied for nesting material.

On the control grids (B and F), all voles caught were ear-tagged with numbered fingerling tags, and released at point of capture after data on sex, weight, and reproductive condition were collected. For males, it was noted whether testes were in an abdominal or scrotal position. For females, the following was noted: vagina perforate or not; nipples small, medium, or large; pubic symphysis closed, slightly open, or open; and pregnant or not. Voles on the removal grids (E and G) were treated similarly, with the same data taken. However, they were not released at point of capture, but were permanently removed from the grid. Voles which colonized the removal grids were defined as dispersers, while voles caught on the control grids were defined as residents ( $\mathrm{T}$ a marin, 1977a).

\subsection{Spatial Distribution}

All voles were classified as belonging to one of 12 possible classes, based on sex, reproductive condition, and age. A male was considered to be in breeding condition if his testes were scrotal. A female was considered to be in breeding condition if her vagina was perforate, or her nipples were either medium or large, or she showed obvious pregnancy. Age classes were determined by weight, according to the criteria of $\mathrm{Krebs}$ et al. (1969) and $\mathrm{Tamarin}$ (1977b). The 12 classes of voles are summarized as follows:

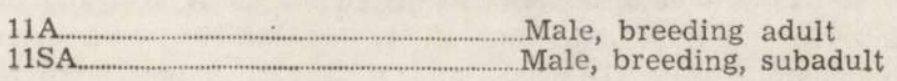


of adjacent captures of a given pair of classes was significantly greater than the expected number, then this was defined as a significant attraction between these two classes. Inversely, if the expected number was greater than the observed number for a given pair, this was defined as a significant avoidance between these pairs.

\subsection{Sequential Trapping}

All instances of a given trap being entered on both Day 1 and Day 2 of a trapping period were tallied. Excluded from this group were all traps which caught the same individual on the two nights of trapping. Each of these observed cases of sequential trap use was classified according to the sex and breeding condition of the Day 1 and Day 2 voles. There are 16 such combinations.

The expected number of cases of sequential trap use for each month for each of the 16 pair categories was determined by multiplying the total monthly observed value by the proportions of the two classes of the pair combination for that month. Since factors such as microhabitat differences, trap sensitivity, and other possible factors may result in the probability of a given trap catching a vole on Day 1 to be altered, we eliminated from further analysis, trap locations at both the high and low ends of the frequency distribution until the point was reached at which the use frequency for all remaining trap locations did not differ significantly (by a chi-square analysis) from the mean use frequency for all trap locations on the grid. This resulted in effective grid sizes of from 72 to 91 trap locations, rather than the original 100 trap grids.

Expected and observed values were compared by the chi-square goodness-offit test. Separate chi-square values were again calculated for each of the four phases of the population cycle of $M$. pennsylvanicus.

\section{RESULTS}

\subsection{Spatial Distribution}

There are 56 cases of on-random associations on all four grids, and these are shown in Table 2. Thirty-eight are avoidances and 18 are attractions, for a ratio of avoidances to attractions 1.1:1. Grids B and $F$ (the resident grids) had the highest number of non-random associations, with 23 and 20, respectively. Grid E, the Muskeget dispersal grid, had 13 significant cases, while grid G, the mainland dispersal grid, had cnly random associations. Out of the 23 cases grid B, the Muskeget resident grid, 17 were avoidances while 6 were attractions, for a ratio of avoidances to attractions of $2.8: 1$. On grid $\mathrm{E}$, the mainland resident grid, the ratio was $2.3: 1$ with 14 cases of avoidance and 6 cases of attraction. On grid $\mathrm{E}$ (Muskeget removal grid), the significant cases represented 7 avoidance and 6 attractions for a ratio of $1.1: 1$. It is interesting to note that all 3 grids had the same number of attractions, and the differences between grid $\mathrm{E}$ and the two resident grids is the reduced number of avoidances on the removal grid.

Male/male, male/female, and female/female interactions accounted for 
11,27 , and 18 of the significant cases, respectively, and the ratios of avoidance to attractions in these three groups were $2.7: 1,2.0: 1$, and $2.0: 1$. In the male/male group, the greatest number of avoidances were seen on the mainland resident grid. All 3 cases of attraction occurred in the same category - nonbreeding subadult males were attracted to each other on all three grids. There were no cases of attraction between breeding males on any grid. In the female/female group, most cases

Table 2

Summary of significant cases of non-random associations between the indicated classes for all four grids. For identification of classes, see text, pages 297-8. Avuidances are indicated by (-), attractions by (+).

\begin{tabular}{|c|c|c|c|}
\hline \multirow{2}{*}{ Interaction } & \multicolumn{2}{|c|}{ Muskeget } & Plymouth \\
\hline & Control, B & Removal, E & Control, F Removal, G \\
\hline Male/Male & $\begin{array}{l}11 \mathrm{~A} / 11 \mathrm{SA}(-)^{*} \\
11 \mathrm{SA} / 11,12(-)^{* *} \\
12 \mathrm{SA} / 12 \mathrm{SA}(+)^{* * *}\end{array}$ & $\begin{array}{l}\text { 11A/12A(-)* } \\
11 \mathrm{~A} / 12 \mathrm{SA}(-)^{*} \\
12 \mathrm{SA} / 12 \mathrm{SA}(+)^{* * *}\end{array}$ & $\begin{array}{l}11 \mathrm{~A} / 12 \mathrm{SA}(-)^{* * *} \\
11 \mathrm{~A} / 12 \mathrm{~J}(-)^{* *} \\
12 \mathrm{SA} / 12 \mathrm{SA}(+)^{*} \\
12 \mathrm{~A} / 12 \mathrm{~J}(-)^{*} \\
12 \mathrm{SA} / 12 \mathrm{~J}(-)^{* * *}\end{array}$ \\
\hline Male/Female & $\begin{array}{l}11 / 21 \mathrm{~A}(+)^{* * *} \\
11 \mathrm{~A} / 21 \mathrm{SA}(+)^{* * *} \\
11 \mathrm{~A} / 21(-)^{* *} \\
11 \mathrm{~A} / 22 \mathrm{~A}(-)^{* * *} \\
11 \mathrm{~A} / 22 \mathrm{SA}(-)^{* * *} \\
11 \mathrm{~A} / 22 \mathrm{~J}(-)^{*} \\
11 \mathrm{SA} / 21(-)^{*} \\
111 / 21,22(-)^{* * *} \\
12 \mathrm{~A} / 21 \mathrm{SA}(-)^{*} \\
12 \mathrm{SA} / 21 \mathrm{~A}(+)^{* * *} \\
12 \mathrm{SA} / 22 \mathrm{SA}(+) * * * \\
12 \mathrm{SA} / 22 \mathrm{~J}(-)^{* * *} \\
12 \mathrm{~J} / 22 \mathrm{SA}(-)^{* * *}\end{array}$ & $\begin{array}{l}11 \mathrm{~A} / 21 \mathrm{~A}(+)^{* *} \\
11 \mathrm{~A} / 21 \mathrm{SA}(+)^{* *} \\
11 \mathrm{~A} / 22 \mathrm{~A}(-)^{*} \\
11 \mathrm{~A} / 22 \mathrm{SA}(-)^{*} \\
11 \mathrm{~A} / 22 \mathrm{~J}(-)^{* * *} \\
12 \mathrm{SA} / 22 \mathrm{SA}(+)^{* * *}\end{array}$ & $\begin{array}{l}11 \mathrm{~A} / 21 \mathrm{~A}(+)^{* * *} \\
11 \mathrm{~A} / 22 \mathrm{~A}(-)^{* * *} \\
11 \mathrm{~A} / 22 \mathrm{~J}(-)^{*} \\
12 \mathrm{~A} / 21 \mathrm{~A}(+)^{* * *} \\
12 \mathrm{SA} / 22 \mathrm{~A}(-)^{* * *} \\
12 \mathrm{SA} / 22 \mathrm{SA}(-)^{*} \\
12 \mathrm{SA} / 22 \mathrm{~J}(-)^{*} \\
12 \mathrm{~J} / 22 \mathrm{~A}(-)^{* * *}\end{array}$ \\
\hline Female/Female & $\begin{array}{l}21 \mathrm{~A} / 21 \mathrm{~A}(+)^{* * *} \\
21 \mathrm{~A} / 21 \mathrm{~J}(-)^{*} \\
21 \mathrm{~A} / 22 \mathrm{~A}(-)^{* * *} \\
21 \mathrm{SA} / 22 \mathrm{~A}(-)^{* *} \\
22 \mathrm{~A} / 22 \mathrm{~A}(-)^{* * *} \\
22 \mathrm{~A} / 22 \mathrm{~J}(-)^{*} \\
22 \mathrm{SA} / 22 \mathrm{~J}(-)^{* * *}\end{array}$ & $\begin{array}{l}21 \mathrm{~A} / 21 \mathrm{~A}(+)^{* * *} \\
21 \mathrm{~A} / 22 \mathrm{SA}(-)^{*} \\
22 \mathrm{SA} / 22 \mathrm{SA}(+)^{*} \\
22 \mathrm{SA} / 22 \mathrm{~J}(-)^{*}\end{array}$ & $\begin{array}{l}21 \mathrm{~A} / 21 \mathrm{~A}(+)^{* * *} \\
21 \mathrm{~A} / 22 \mathrm{SA}(+)^{* *} \\
21 \mathrm{~A} / 22 \mathrm{~J}(+)^{*} \\
21 \mathrm{SA} / 21,22(-)^{*} \\
22 \mathrm{~A} / 22 \mathrm{SA}(-)^{* * *} \\
22 \mathrm{~A} / 22 \mathrm{~J}(-)^{* *} \\
22 \mathrm{SA} / 22 \mathrm{~J}(-)^{* *}\end{array}$ \\
\hline \multicolumn{4}{|l|}{$\begin{array}{rl}* & p<.05 \\
* * & p<.01 \\
* * * & p<.005\end{array}$} \\
\hline \multicolumn{4}{|c|}{$\begin{array}{l}\text { of avoidance were seen by nonbreeding females for other nonbreeding } \\
\text { females. Adult breeding females were attracted to each other on all } \\
\text { three grids. In interactions between breeding and nonbreeding females, } \\
\text { attractions were more important on grid } \mathrm{F} \text {, and avoidances were more } \\
\text { important on the island grids (B and } \mathrm{E} \text { ). Most of the interactions in the }\end{array}$} \\
\hline
\end{tabular}


male/female group were seen on the island resident grid. Most cases of attraction in this group occurred between breeding males and breeding females on all three grids. Avoidances were seen between breeding males and nonbreeding females, and between nonbreeding males and females. These latter avoidances were more important on grid $\mathrm{F}$ (mainland resident) than on grid $\mathrm{B}$ (Muskeget resident).

The results of the analysis of social distribution during the four phases of the population cycle in $M$. pennsylvanicus are summarized in Table 3 . On grid $\mathrm{F}$, there are 26 significant cases of non-random associations occurring in a particular phase of the cycle. Nineteen of

Table 3

Summary of the significant cases of non-random association between the indicated classes, broken down into individual phases of the population cycle on mainland grids F and G. For identification of classes, see text, pages 297-8. Avoidances are indicated by $(-)$, attractions by $(+)$.

\begin{tabular}{|c|c|c|c|c|}
\hline \multirow[b]{2}{*}{ Interaction } & \multicolumn{3}{|c|}{ Grid F (Control) } & \multirow{2}{*}{$\frac{\text { Grid G (Removal) }}{\text { Decrease }}$} \\
\hline & High & Decrease & Increase & \\
\hline Male/Male & $\begin{array}{l}11 \mathrm{~A} / 11 \mathrm{~A}(-)^{*} \\
11 \mathrm{~A} / 12 \mathrm{SA}(-)^{*} \\
11 \mathrm{~A} / 12 \mathrm{~J}(-)^{*} \\
12 \mathrm{~A} / 12 \mathrm{SA}(+)^{*} \\
12 \mathrm{SA} / 12 \mathrm{SA}(+)^{*} \\
12 \mathrm{SA} / 12 \mathrm{~J}(-)^{* * *}\end{array}$ & $\begin{array}{l}12 \mathrm{~A} / 12 \mathrm{~A}(+)^{*} \\
12 \mathrm{SA} / 12(-)^{*}\end{array}$ & $11 \mathrm{~A} / 12(-)^{*}$ & $12 \mathrm{~A} / 12(+)^{*}$ \\
\hline Male/Female & $\begin{array}{l}11 \mathrm{~A} / 21 \mathrm{~A}(+)^{* *} \\
11 \mathrm{~A} / 22 \mathrm{~A}(-)^{* * *} \\
11 \mathrm{~A} / 22 \mathrm{~J}(-)^{*} \\
12 \mathrm{~A} / 21 \mathrm{~A}(+)^{* * *} \\
12 \mathrm{SA} / 22 \mathrm{~J}(-)^{* * *} \\
12 \mathrm{~J} / 21 \mathrm{~A}(-)^{* * *} \\
12 \mathrm{~J} / 22 \mathrm{~A}(-)^{* * *}\end{array}$ & $\begin{array}{l}12 \mathrm{~A} / 22 \mathrm{SA}(+)^{* * *} \\
12 \mathrm{SA} / 21,22(-)^{*}\end{array}$ & $12 \mathrm{SA} / 21,22(-)^{*}$ & $12 \mathrm{~A} / 21,22(+)^{*}$ \\
\hline Female/Female & $\begin{array}{l}21 \mathrm{~A} / 21 \mathrm{~A}(+)^{* * *} \\
21 \mathrm{~A} / 21 \mathrm{SA}(+)^{*} \\
21 \mathrm{~A} / 22 \mathrm{SA}(+)^{*} \\
21 \mathrm{~A} / 22 \mathrm{~J}(+)^{*} \\
22 \mathrm{~A} / 22 \mathrm{~J}(-)^{* *} \\
22 \mathrm{SA} / 22 \mathrm{~J}(-)^{*}\end{array}$ & $22 / 22(+)^{*}$ & & \\
\hline
\end{tabular}

$$
\begin{array}{rl}
* & p<.05 \\
* * & p<.01 \\
& p<.005
\end{array}
$$

these cases occur during the high phase, 5 during the decrease phase, 2 during the increase phase, and none during the low phase. Of these 26 cases, 15 are avoidances and 11 are attractions, for a ratio of 1.4:1. During the high phase, there are 11 cases of avoidance and 8 cases of attraction. In the decrease phase there are 3 cases of attraction and 2 cases of avoidance, while the increase phase shows 2 cases of avoidance and no attractions. 


\subsection{Sequential Trap Use}

There are 7 out of 64 cases which reach at least the .05 level of significance, and these are shown in Table 4. Three of the significant cases are attractions while 4 are avoidances. The Muskeget Island grids account for only 2 significant cases, one an attraction and one an avoidance, and both appearing on grid B (resident grid), while the mainland shows 5 significant cases, 4 on the resident grid ( 2 attractions and 2 avoidances) and one on the removal grid (an avoidance).

\section{Table 4}

Chi-square values for pair combinations of sequential trap use analysis for all four grids. Avoidances are indicated by $(-)$, attractions by $(+)$. C indicates that the category was analyzed as part of a combined category and found to be not significant. $\mathrm{Br}$ refers to breedding and $N B$ to nonbreeding individuals.

\begin{tabular}{|c|c|c|c|c|}
\hline \multirow[b]{2}{*}{ Interaction } & \multicolumn{2}{|c|}{ Muskeget } & \multicolumn{2}{|c|}{ Plymouth } \\
\hline & $\begin{array}{c}\text { Control } \\
\text { B }\end{array}$ & $\underset{\mathbf{E}}{\text { Removal }}$ & $\underset{\mathrm{F}}{\text { Control }}$ & $\underset{\mathrm{G}}{\text { Removal }}$ \\
\hline \multicolumn{5}{|l|}{ Male/Male } \\
\hline $\mathrm{Br} / \mathrm{Br}$ & 1.69 & 0.11 & 0.71 & 0.99 \\
\hline $\mathrm{Br} / \mathrm{NB}$ & 1.52 & 0.72 & 0.07 & 2.32 \\
\hline $\mathrm{NB} / \mathrm{Br}$ & 1.52 & 0.40 & 1.67 & 0.03 \\
\hline$N B / N B$ & 0.03 & 0.00 & 0.00 & 0.03 \\
\hline \multicolumn{5}{|l|}{ Male/Female } \\
\hline $\mathrm{Br} / \mathrm{Br}$ & 0.87 & 0.00 & 0.21 & $\mathrm{C}$ \\
\hline$B r / N B$ & 0.91 & 1.02 & 2.27 & $\mathrm{C}$ \\
\hline$N B / N B$ & 0.46 & 0.99 & 2.57 & C \\
\hline $\mathrm{NB} / \mathrm{Br}$ & 0.09 & 0.40 & $7.90(-)^{* * *}$ & $\mathrm{C}$ \\
\hline \multicolumn{5}{|l|}{ Female/Male } \\
\hline $\mathrm{Br} / \mathrm{Br}$ & $30.37(+)^{* * *}$ & 0.06 & $6.85(+)^{* *}$ & 0.00 \\
\hline $\mathrm{Br} / \mathrm{NB}$ & 2.95 & 1.45 & 0.81 & 3.20 \\
\hline$N B / N B$ & 0.00 & 1.22 & $6.15(+)^{*}$ & 0.05 \\
\hline $\mathrm{NB} / \mathrm{Br}$ & 0.14 & 0.28 & 0.98 & 0.01 \\
\hline \multicolumn{5}{|l|}{ Female/Female } \\
\hline $\mathrm{Br} / \mathrm{Br}$ & $6.20(-)^{*}$ & 0.90 & 0.07 & C \\
\hline$B r / N B$ & 0.09 & 0.02 & 0.58 & $\mathrm{C}$ \\
\hline $\mathrm{NB} / \mathrm{Br}$ & 0.00 & 0.36 & $4.72(-)^{*}$ & $5.40(-)^{*}$ \\
\hline$N B / N B$ & 0.06 & 1.24 & 0.01 & C \\
\hline
\end{tabular}

$* p<.05$

$* * p<.01$

$* * * \quad p<.005$

There are no cases of males being attracted to or avoiding other males on any grid. The strongest attractions are of breeding males for breeding females, occuring on grids $\mathrm{B}$ and $\mathrm{F}$ (the resident grids). Two cf the strongest avoidances involve breeding females for other females, occurring in both species. When the data for each phase of the cycle were analyzed separately, there were no significant cases of attraction or avoidance. 


\section{DISCUSSION}

This discussion will focus on three topics - differences between the two species, Microtus pennsylvanicus and $M$. brenweri, differences between residents and dispersers of each species, and differences between the various phases of the population cycle in $M$. pennsylvanicus.

\subsection{Spatial Distribution}

In terms of spatial distribution, Microtus pennsylvanicus on grid $\mathrm{F}$ and $M$. breweri on grid B show similar patterns, but have interesting differences. In each, the number of significant deviations from randomness in both the attraction and avoidance directions is about the same, as is the pattern of interactions between males and females. However, in $M$. pennsylvanicus, we see that avoidances between males, particularly nonbreeding males, are more important than they are in $M$. breweri, which shows considerably more avoidances between females, primarily in the nonbreeding category. Within a species, avoidances by $M$. pennsylvanicus are no more important in males than they are in females, while in $M$. breweri, avoidances between females are more important than avoidances between males.

More striking differences are apparent when the dispersers of the two species are compared. Microtus breweri dispersers (grid E) showed 13 cases of significant non-random association, while $M$. pennsylvanicus dispersers (grid G) did not show any at all. Within a species, $M$. breweri residents show many more cases of avoidance than do dispersers, while the number and distribution of attractions are about the same in these two grids. Residents and dispersers were most similar in male/male interactions, and least similar in female/female interactions. Female/ female avoidances were more important on the resident grid than on the dispersal grid. Residents and dispersers of $M$. pennsylvanicus differ markedly, considering that the dispersal grid shows no cases of significant non-random associations. Hence, attractions and avoidances between all classes are more important on the resident grid.

When each phase of the population cycle is examined separately in M. pennsylvanicus, we see that on grid F, most non-random cases (15 cut of 20) occur during the high phase, where there are more cases cf attraction than of avoidance.

Examining the data closely, it appears that there is a trend in number of significant cases of non-random association and population density. Peak densities of $M$. pennsylvanicus on grid $F$ approached the level maintained by $M$. breweri on grid B. The dispersing sub-population of $M$. breweri on grid $\mathrm{E}$ had a maximum density somewhat lower than 
that on grid B, while the dispersing sub-population of $M$. pennsylvanicus on grid $\mathrm{G}$ had a much lower density than the grid $\mathrm{F}$ population ( $\mathrm{T}$ a $\mathrm{m}$ arin, 1977b). This is the same order as the ordering of number of significant comparisons.

A difference is social behavior related to density is predicted by Chitty's (1967) hypothesis. We would expect from the hypothesis that as the population density increases to its peak, the level of social intolerance should also increase. If our analysis of deviation from random spatial distribution is in fact a valid measure of social interactions, then we see that the level of social interaction at the peak seems to predict the decline in $M$. pennsylvanicus. But why doesn't a similar level of social interaction bring about a decline in $M$. breweri? The answer lies in the nature of the dispersers, as predicted by $\mathrm{T}$ a $\mathrm{m}$ ar in $(1977 b, 1978)$. The dispersers of $M$. breweri do not differ as much from the residents, as dispersers and residents of $M$. pennsylvanicus differ from each other. Dispersal in $M$. breweri, then, might not bring about the genotypic alteration that Chitty's hypothesis says is necessary for a decline to occur. Yet we do see differences between dispersers and residents in $M$. breweri in this study, and these differences relate mostly to the degree of avoidances. Perhaps this is an important factor in the regulation of $M$. breveri at high density. There is constant dispersal from the population, not of the socially intolerant individuals as in $M$. pennsylvanicus, but of a class of voles who would avoid agonistic interactions, and continue with a social distribution characterized by a relatively higher level of attractive interactions. These voles may be classified as non-aggressive. The relationship between levels of social intolerance between resident and dispersing voles may be sufficient to account for the demographic differences between the two species.

\subsection{Sequential Trap Use}

The analysis of sequential trap use is a modification of a commonly used laboratory procedure. The response of individuals to urine of conspecifics has been studied in a variety of rodents (A u gust, 1978; Murphy \& Schneider, 1970). Similar experiments have been performed in the field (Summerlin \& Wolfe, 1974; Mazdzer et al., 1976). However, each of these experiments involved the investigator introducting a scent obtained in the laboratory or under artificial handling conditions. In the present study, the scents were left in the trap by trapped voles. Thus, urine was produced under conditions which more closely resembled natural conditions.

We noted 3 cases of attraction and 4 cases of avoidance of voles of a given age/sex class to scents left in traps by voles of another given 
age/sex class. It is seen that $M$. pennsylvanicus has more significant deviations that does $M$. breweri. Within a species, both $M$. pennsylvanicus and $M$. breweri show more deviations in the resident than in the dispersing sub-populations. The statistically significant deviations in $M$. pennsylvanicus lose their significance when each phase of the cycle is analyzed separatelly. Thus, it appears that the attraction and avoidance of individuals based on olfactory cues, as determined by this method, is not related to major demographic changes.

All of the cases of attraction fall into the category of males being attracted to the scents of females. There are no cases of females being attracted to the scents of males, or of same-sex attraction. The strongest cases of attraction involve the attraction of males in breeding condition for females in breeding condition. The attraction of rodents for members of the opposite sex through olfactory cues has been demonstrated in many other species (A u g u st, 1978; Le Mag n e n, 1951), and it has been suggested that this functions to improve the ability to locate mates.

Most of the avoidances are seen in female/female interactions, particularly as avoidances by breeding females for breeding and nonbreeding females. There are no instances of males avoiding each other. Thus, it appears that while breeding females actively avoid other females, they are passive with regard to male attraction, appearing to wait for males to be attracted to them. Perhaps female social structure is important in population regulation, as was suggested by $\mathrm{B} \mathrm{u} \mathrm{jal} \mathrm{ska}$ (1970).

If this attraction and avoidance of individuals by olfactory cues is independent of major demographic changes as is suggested here, then upon what factors is it based? The pattern of significant cases suggests that breeding condition is the most important factor. Turner \& I vers on (1973) suggest that cycles of aggression in $M$. pennsylvanicus are independent of demographic changes, and are more influencèd by the reproductive cycle. The data presented here seem to support this view. It also appears that there is not a strong relationship between the response to olfactory cues and social distribution, indicating that some mechanism other than olfaction must be important in determining the social structure in both species.

Acknowledgments: This work was supported by NIH grants HD06621 and HD11682 and grants from the Boston University Graduate School to Tamarin. Part of this paper were submitted by Reich as a thesis in partial fulfillment of the M. A. degree in Biology. We thank Fred Wasserman for statistical advice. 


\section{REFERENCES}

1. A ugust P. V., 1978: Scent communication in the southern plaints woodrat, Neotoma micropus. Amer. Midl. Nat., 99: 206-218.

2. B oonstra R. \& Krebs C., 1976: The effect of odour on trap response in Microtus townsendii. J. Zool., Lond., 180: 467-476.

3. Bujalska G., 1970: Reproduction stabilizing elements in an island population of Clethrionomys glareolus (Schreber, 1780). Acta theriol., 15: 381-412.

4. Chitty D., 1967: The natural selection of self-regulatory behavior in animal populations. Proc. Ecol. Soc. August., 2: 51-78.

5. Conley W. H., 1971: Behavior, demography and competition in Microtus longicaudus and $M$. mexicanus. Ph.D. Thesis, Texas Tech Univ.

6. Dagg A. I. \& Windsor D. E., 1971: Olfactory discrimination limits in gerbils. Can. J. Zool., 49: 283-285.

7. Elt on C., 1924: Periodic fluctuations in the number of animals: their causes and effects. Br. J. Exp. Biol., 2: 119-163.

8. Getz L. L., 1972: Social structure and aggressive behavior in a population of Microtus pennsylvanicus. J. Mamm., 53: 310-317.

9. Johns on R. P., 1973: Scent marking in mammals. Anim. Behav., 21: 521-535 .

10. Krebs C. J., 1970: Microtus population biology: behavioral changes associated with the population cycle in $M$. ochrogaster and $M$. pennsylvanicus. Ecology, 51: $34-52$.

11. Krebs C. J., Gaines M. S., Keller B. L., Myers J. H., T a mar in R. H., 1973: Population cycles in small rodents. Science, 179: 35-41.

12. Krebs C. J., Keller B. L., \& T a marin R. H., 1969: Microtus population biology: demographic changes in fluctuating populations of $M$. ochrogaster and $M$. pennsylvanicus in southern Indiana. Ecology, 50: 587-607.

13. Krebs C. J. \& Myers J. H., 1974: Population cycles in small mammals. Adv. Ecol. Res., 8: 267-399.

14. Le Magnen J. 1951: Etude des phenomenes olfacto-sexuels chez le rat blanc. C. R. Seances Soc. Biol. Fil., 145: 851-860.

15. Mazdzer E., Capone M. R., \& Drickamer L. C., 1976: Conspecific odors and trappability of deer mice (Peromyscus leucopus noveboracensis). J. Mamm., 57: 607-609.

16. Murphy M. R. \& Schneider G. E., 1970: Olfactory bulb removal eliminates mating behavior in the male golden hamster. Science, 167: 302-304.

17. Myers J. H. \& Krebs C. J., 1971: Genetic, behavioral, and reproductive attributes of dispersing field voles, Microtus pennsylvanicus and Microtus ochrogaster. Ecol. Monogr., 41: 53-78.

18. R a $11 \mathrm{~s} \mathrm{~K}$., 1971: Mammalian scent marking. Science, 171: 443-449.

19. Summerlin C. T. \& Wolfe J. L., 1973: Social influences on trap response in the cotton rat, Sigmodon hispidus. Ecology, 54: 1156-1159.

20. T a m a r in R. H., 1977a: Dispersal in island and mainland voles. Ecology, 58: $1044-1054$.

21. Tamarin R. H., 1977b: Demography of the beach vole (Microtus breweri) and the meadow vole (Microtus pennsylvanicus) in southeastern Massachusetts. Ecology, 58: 1310-1321.

22. Tamarin R. H., 1978: Dispersal, population regulation, and K-selection in field mice. Amer. Nat., 112: 545-555.

23. Turner B. N. \& Ivers on S. L., 1973: The annual cycle of aggression in 
male Microtus pennsylvanicus, an'd its relation to population parameters. Ecology, 54: 967-981.

24. Wetherbee D. K., Coppinger R. P. \& Walsh R. E., 1972: Time Lapse Ecology, Muskeget Island, Nantucked County, Massachusetts. MSS Educational Publ. New York.

Accepted, April 15, 1980

Lawrence M. REICH i Robert H. TAMARIN

WYKORZYSTANIE PUŁAPEK JAKO WSKAŹNIK BEHAWIORU SOCJALNEGO
NORNIKOW

Streszczenie

Badano behawior socjalny u Microtus pennsylvanicus w populacji o cyklicznych zmianach liczebności (Tabela 1) i niepodlegającej zmianom populacji endemicznej $M$. breweri $\mathrm{z}$ wyspy. Strukturę socjalną określano na podstawie przestrzennego rozmieszczenia różnych grup płciowych, rozrodezych i wiekowych tych gatunków lowionych w żywołówki (Tabela 2). Badano również w warunkach terenowych reakcję norników z różnych klas wiekowych i płciowych na bodźce zapachowe związane z używaniem żywołówek przez inne norniki, o znanym wieku i płci. Różnice w behawiorze socjalnym między dwoma gatunkami rozpatrywano również pod kątem ich udziału w obserwowanych różnicach demograficznych między tymi gatunkami. Porównywano osiadłe i rozproszone sub-populacje każdego gatunku. Behawior socjalny badano też w każdej z 4 faz pojedynczego cyklu populacyjnego $M$. pennsylvanicus (Tabela 3). Zauważono, że natężenie socjalnych interakcji wzrasta znacznie ze wzrostem zagęszczenia populacji (Tabela 4). Osobniki migrujące $\mathrm{z}$ cyklicznych populacji norników ( $M$. pennsylvanicus) wykazują losowy rozklad struktury socjalnej, być może wskazujący na socjalną nietolerancję. Migrująca część niecyklicznej populacji $M$. breweri nie wykazuje tej socjalnej nietolerancji, ale jest mniej agresywna w porównaniu z osiadlymi osobnikami tego samego gatunku. Uważa się, że jest to podstawowy czynnik różnicujący dynamikę populacji obu gatunków. Analiza reakcji na bodźce węchowe związane z pułapkami wskazuje na to, że ma ona przede wszystkim związek z rozrodem i nie zależy od zmian demograficznych u $M$. pennsylvanicus. Nie jest ona istotnym czynnikiem determizującym strukturę socjalną obu badanych gatunków. 